\title{
Serum Total Cholesterol Measurement
}

National Cancer Institute

\section{Source}

National Cancer Institute. Serum Total Cholesterol Measurement. NCI Thesaurus. Code C61032.

A quantitative measurement of the total amount of cholesterol present in a sample of serum. 